\title{
Innovative policy practices to advance building energy efficiency and retrofitting: Approaches, impacts and challenges in ten $\mathrm{C} 40$ cities
}

\author{
Accepted manuscript (July 2016) for \\ Environmental Science and Policy \\ Special Edition \\ Climate Change in the Urban \\ Environment: Advancing, \\ Measuring and Achieving Resiliency \\ http://dx.doi.org/10.1016/j.envsci.2016.06.021 \\ See journal website for final version
}

\author{
Gregory Trencher (corresponding author) \\ Clark University: Department of International Development, Community and \\ Environment, Worcester, USA. \\ gtrencher@clarku.edu \\ Vanesa Castán Broto \\ University College London: Faculty of the Built Environment \\ Tomoko Takagi \\ CSR Design Green Investment Advisory, Tokyo \\ Zoe Sprigings \\ C40 Cities Climate Leadership Group, London \\ Yuko Nishida \\ Tokyo Metropolitan Government - Bureau of Environment, Tokyo \\ Masaru Yarime \\ University of Tokyo: Graduate School of Public Policy, Tokyo, Japan \\ University College London: Dept. Science, Technology, Engineering \& Public Policy
}




\section{Abstract}

This study examines ten programmes to advance energy efficiency and retrofitting of existing, private sector buildings in C40 cities in Asia-Pacific and USA. We set out to identify differing policy approaches, together with potential impacts and implementation challenges for each. Findings unearthed six policy models-both mandatory and voluntary - with unique impacts and challenges. We demonstrate that innovation occurs without new policy inventions and largely by necessity, as new features are added and generic models are adapted to local circumstances. Our sample demonstrated experimentation with benchmarking in the USA, comprehensive regulation in Asia, and voluntary approaches in Australia. Overall, environmental impacts are particularly slow to emerge and plagued with attribution challenges. We found limited evidence of benchmarking programme effectiveness in reducing energy consumption in the shortterm, but some indication of mid-term outcomes. Driven by unique local circumstances, the cap-and-trade model stood out by fostering rapid, sustained and attributable GHG emission reductions and retrofitting. Market and social impacts are highly significant across all programmes, highlighting needs to consider non-environmental impacts in policy evaluation. We emphasise the complementary potential of voluntary and regulatory approaches to advancing energy efficiency and climate resilience. We also underscore the potential for reporting or benchmarking programmes to later transition to models mandating performance improvements, such as cap-and-trade. 


\section{Introduction}

Given the global imperative to reduce GHG emissions and fossil fuel consumption, expectations are mounting for city governments to innovate and develop effective policies for urban climate, energy and resilience challenges (Bulkeley, 2015; World Bank, 2010). Wielding direct control over local laws and much built environment infrastructure, cities can function as 'laboratories' or experiment zones for showcasing emerging forms of governance (Castan Broto and Bulkeley, 2013; Bulkeley et al., 2014a). With much progress worldwide in renewable energy policies such as feed-in tariffs and subsidies (Brown, 2015), policymaker attention is increasingly shifting towards reducing fossil fuel consumption and GHG emissions in buildings.

In 2010 , the global building stock represented $34 \%$ of final energy use and $24 \%$ of energy-related GHG emissions (IPCC, 2014). In mega cities such as New York, Hong Kong, San Francisco and Tokyo, these figures are closer to double, with building GHG emissions and energy consumption dwarfing other sectors such as transport. Building stocks require decades to replace. They thus contribute to 'carbon lock-in', heavily influencing future efforts to decrease GHG emissions and boost climate resilience (IPCC, 2014). Although industrialised nation cities have advanced measures to improve energy efficiency in new construction (Van Der Heijden, 2014), decarbonisation of existing buildings remains an unsolved challenge (Dowling et al., 2014), demanding unprecedented levels of policymaking innovation.

Novelty and pioneering behaviour is integral to innovation. Yet what is deemed 'new' is purely contextual, since very few policies are novel in a global sense (Howlett, 2014). 
Instead, bureaucrat 'policy entrepreneurs' innovate by learning and appropriating policy models from frontrunner peers (Bulkeley, 2010; Matisoff and Edwards, 2014). Global networks such as C40 Cities Climate Leadership Group (henceforth C40) or ICLEI Climate Cities Program (Acuto, 2016) can spur this by enabling collective learning amongst policymakers from exemplary or pioneering practices. In addition, policymaker learning and innovation is fuelled by 'intermediaries' (Guy et al. 2010). These include NGOs, private sector actors and government agencies that mediate across societal sectors to foster novel practices and socio-technical change in urban infrastructure. Global networks therefore constitute rich opportunities for examining innovation in urban climate change governance.

Three potential angles of inquiry are highlighted by Jordan and Huitema (2014a, 2014c) for studying climate policy innovation: (1) invention-formulation of novel policies or elements; (2) diffusion-adoption of innovative policies; and (3) evaluation-assessment of impacts. Although related scholarship has burgeoned in recent years, significant gaps remain. These concern particularly how similar policies are modified to suit local circumstances (Biesenbender and Tosun, 2014) or evaluated (Auld et al., 2014; Jordan and Huitema, 2015; Hilden et al., 2014). Regarding evaluation, as increasing numbers of cities experiment with emerging or unproven policies for climate and energy challenges (Auld et al., 2014; Castan Broto and Bulkeley 2013), needs for knowledge on actual or potential effects are growing. Policies to advance energy efficiency, retrofitting and GHG emission reductions in buildings are laden with high expectations since they are core components of wider and often politically ambitious city climate targets. Yet lack of monitoring and uncertainty of results can deter innovation and risk-taking (Huag et al., 
2010). Knowledge on differing potential impacts is therefore vital for cities weighing up multiple policy options (Van Der Heijden, 2015).

Responding to these cues, we gathered evidence from ten C40 cities in Asia-Pacific (Hong Kong, Melbourne, Sydney, Singapore and Tokyo) and the USA (Houston, New York, Seattle, San Francisco and Philadelphia). Heeding calls for cross-national and comparative studies in climate governance (Castan Broto and Bulkeley, 2013), we focus specifically on ten individual city programmes to advance energy efficiency and retrofitting in existing, private sector buildings. Data is sourced from city officials via questionnaires, interviews, documents and literature. Assuming that policy inventions are rare (Howlett, 2014) and that few cities design policies from scratch (Jordan and Huitema, 2014c), we examine diffusion and evaluation aspects as follows. Sets of research questions are answered separately in Sections 3 and 4:

(Diffusion): What are key policy models used in flagship programmes from C40 cities in Asia-Pacific and USA to advance energy efficiency in existing, private buildings? How were generic models adapted to local circumstances?

(Evaluation): For each model, what types of impacts and challenges for policymakers could be expected if implementing elsewhere? 


\section{Methods}

This study examines experiences of policymakers and implementers in ten cities actively participating in the C40 working group Private Building Efficiency Network $(\mathrm{PBEN})^{1}$. It builds on data gathered during January-December 2014 for research commissioned by the Tokyo Metropolitan Government (TMG) and C40 London (Takagi et al. 2014). Our sample (Table 1) comprises one individual programme ${ }^{2}$ from each city agreeing to participate in our study. Each city was invited to nominate one innovative, flagship programme seeking to advance energy efficiency and retrofitting in existing, private buildings. Although cities often have multiple such programmes, analysis was limited to one to ensure obtainment of detailed, descriptive information. Data was collected principally via three methods: 1) written questionnaires, 2) semi-structured telephone conference interviews and 3) document analysis.

Questionnaires were administered electronically to each city in April 2014. These gathered basic qualitative and quantitative information for areas such as: programme objectives, scope and attributes of targeted buildings; various impacts observed; and design and implementation phase challenges. Semi-structured telephone interviews were held during March-April 2014 to collect detailed qualitative data. Each lasted 90minutes and involved one or two officials from the interviewed city, the Tokyo research team, and representatives from TMG and C40 London. Conversations were recorded, transcribed into minutes and analysed manually. Document analysis lasted from April

\footnotetext{
${ }^{1}$ This working group of $\mathrm{C} 40$ is currently comprised of approximately 30 members across Asia, Oceania, Africa, Europe, and North and Latin America.

2 This term depicts the interconnected package of policies, laws, regulations and support mechanisms that make up a unified city-driven initiative to advance energy efficiency and retrofitting in existing buildings.
} 
2014 to April 2016 and involved review of official city webpages and programme reports, in addition to third-party material such as scholarly publications and grey literature. Additionally, city officials were contacted via email on multiple occasions to ensure accuracy of data and interpretations or obtain further information. 


\section{Table 1 Surveyed cities and programmes}

\begin{tabular}{|c|c|c|c|c|c|c|c|}
\hline $\begin{array}{l}\text { Jurisdiction }{ }^{\mathrm{a}} \& \\
\text { programme name }\end{array}$ & Policy model(s) & $\begin{array}{l}\text { Target building } \\
\text { type }\end{array}$ & $\begin{array}{l}\text { Citywide } \mathrm{CO}_{2} \\
\text { target }\end{array}$ & $\begin{array}{l}\text { Share citywide } \\
\text { building GHGs } \\
\text { (residential \& } \\
\text { commercial) }\end{array}$ & $\begin{array}{l}\text { First year } \\
\text { implemented }^{\mathrm{b}}\end{array}$ & $\begin{array}{l}\text { Citywide }{ }^{a} \text { buildings } \\
\text { targeted }\end{array}$ & $\begin{array}{l}\text { Citywide }{ }^{a} \text { floor area } \\
\text { affected }\end{array}$ \\
\hline \multicolumn{8}{|l|}{ City of Houston } \\
\hline $\begin{array}{l}\text { Houston Green Office } \\
\text { Challenge }\end{array}$ & $\begin{array}{l}\text { Friendly } \\
\text { competition }\end{array}$ & $\begin{array}{l}\text { Commercial } \\
\text { (office) }\end{array}$ & $\begin{array}{l}-36 \% \text { by } 2016 \\
\text { from } 2007 \text { levels }\end{array}$ & $52 \%$ (in 2014) & 2011 & $\begin{array}{l}52 \text { (buildings/tenants in } \\
2014 / 15 \text { ) }\end{array}$ & $3,483,864 \mathrm{~m}^{2}$ (in 2014/15) \\
\hline \multicolumn{8}{|l|}{ City of Melbourne } \\
\hline 1200 Buildings & Capacity building & $\begin{array}{l}\text { Commercial } \\
\text { (office) }\end{array}$ & $\begin{array}{l}-100 \% \text { by } 2020 \\
\text { from } 2006 \text { levels }\end{array}$ & $63 \%$ (in 2012) & 2010 & $\begin{array}{l}\text { - Overall programme: } \\
1200 \\
\text { - Signatory } \\
\text { programme: } 57 \text { (in } \\
\text { 2015) }\end{array}$ & $\begin{array}{l}\text { - } 1,669,925 \mathrm{~m}^{2} \text { (formal } \\
\text { signatories in 2015) } \\
\text { - } 22 \% \text { of office-space } \\
\text { containing buildings } \\
\text { (formal signatories in } \\
2015 \text { ) }\end{array}$ \\
\hline \multicolumn{8}{|l|}{ City of New York } \\
\hline $\begin{array}{l}\text { Greener, Greater } \\
\text { Buildings Plan }\end{array}$ & $\begin{array}{l}\text { - Benchmarking } \\
\text { - Periodical } \\
\text { energy efficiency } \\
\text { auditing or retro- } \\
\text { commissioning } \\
\text { - Energy } \\
\text { efficiency } \\
\text { standards }\end{array}$ & $\begin{array}{l}\text { - } \text { Commercial } \\
\text { - Public } \\
\text { - Residential } \\
\text { (multifamily) }\end{array}$ & $\begin{array}{l}-80 \% \text { by } 2050 \\
\text { from } 2005 \text { levels }\end{array}$ & $74 \%$ (in 2013) & 2011 & 23,417 (in 2013) & $\begin{array}{l}\text { - } 213,676,991 \mathrm{~m}^{2} \text { (in 2013) } \\
\text { - } 52 \% \text { of citywide floor } \\
\text { area }\end{array}$ \\
\hline \multicolumn{8}{|l|}{ City of Philadelphia } \\
\hline $\begin{array}{l}\text { Building Energy } \\
\text { Benchmarking } \\
\text { Ordinance }\end{array}$ & - Benchmarking & Commercial & $\begin{array}{l}-20 \% \text { by } 2015 \\
\text { from } 1990 \text { levels }\end{array}$ & $61 \%$ (in 2012) & 2013 & 2,094 (in 2015) & $\begin{array}{l}\text { - } 25,083,820 \mathrm{~m}^{2} \text { (in } 2014 \text { ) } \\
\text { - } 25 \% \text { of citywide floor } \\
\text { area }\end{array}$ \\
\hline \multicolumn{8}{|l|}{ City of San Francisco } \\
\hline $\begin{array}{l}\text { Existing Commercial } \\
\text { Buildings Energy } \\
\text { Performance } \\
\text { Ordinance }\end{array}$ & $\begin{array}{l}\text { - Benchmarking } \\
\text { - Periodical } \\
\text { energy efficiency } \\
\text { auditing or retro- } \\
\text { commissioning }\end{array}$ & Commercial & $\begin{array}{l}-80 \% \text { by } 2050 \\
\text { from } 1990 \text { levels }\end{array}$ & $52 \%$ (in 2013) & 2011 & 1,847 (in 2015) & $14,269,906 \mathrm{~m}^{2}$ (in 2015) \\
\hline
\end{tabular}




\begin{tabular}{|c|c|c|c|c|c|c|c|}
\hline \multicolumn{8}{|l|}{ City of Seattle } \\
\hline $\begin{array}{l}\text { Seattle Building } \\
\text { Energy Benchmarking } \\
\text { and Reporting }\end{array}$ & Benchmarking & $\begin{array}{l}\text { - } \text { Commercial } \\
\text { - Residential } \\
\text { (multifamily) }\end{array}$ & $\begin{array}{l}-100 \% \text { by } 2050 \\
\text { from } 2008 \text { levels }\end{array}$ & $21 \%$ (in 2013) & 2012 & 3,240 (in 2014) & $26,105,754 \mathrm{~m}^{2}$ (in 2013) \\
\hline \multicolumn{8}{|l|}{ City of Sydney } \\
\hline $\begin{array}{l}\text { Smart Green } \\
\text { Apartments }\end{array}$ & Capacity building & $\begin{array}{l}\text { - } \\
\text { (multifamily) }\end{array}$ & $\begin{array}{l}-70 \% \text { by } 2030 \\
\text { from } 2006 \text { levels }\end{array}$ & $49 \%$ (in 2009) & 2011 & 30 (in 2012-13) & No data available \\
\hline \multicolumn{8}{|l|}{ Hong Kong } \\
\hline $\begin{array}{l}\text { Buildings Energy } \\
\text { Efficiency Ordinance }\end{array}$ & $\begin{array}{l}\text { - Periodical } \\
\text { energy efficiency } \\
\text { auditing or retro- } \\
\text { commissioning } \\
\text { - Energy } \\
\text { efficiency } \\
\text { standards } \\
\end{array}$ & $\begin{array}{l}\text { - Commercial } \\
\text { - Public }\end{array}$ & $\begin{array}{l}-50 \% \text { to }-60 \% \\
\text { carbon intensity } \\
\text { by } 2020 \text { from } \\
2005 \text { levels }\end{array}$ & $61 \%$ (in 2012) & 2012 & $\begin{array}{l}\text { Majority of } 42,000 \\
\text { commercial and public } \\
\text { buildings (in 2012) }\end{array}$ & $\begin{array}{l}\text { Majority of commercial and } \\
\text { public buildings }\end{array}$ \\
\hline \multicolumn{8}{|l|}{ Singapore } \\
\hline $\begin{array}{l}\text { Legislation for Existing } \\
\text { Buildings }\end{array}$ & $\begin{array}{l}\text { - Benchmarking } \\
\text { - Periodical } \\
\text { energy efficiency } \\
\text { auditing or retro- } \\
\text { commissioning } \\
\text { - Energy } \\
\text { efficiency } \\
\text { standards }\end{array}$ & Commercial & $\begin{array}{l}-11 \% \text { by } 2020 \\
\text { from BAU levels }\end{array}$ & $37 \%$ (in 2014) & 2013 & $\begin{array}{l}1,060^{\mathrm{c}} \text { (in 2014) for } \\
\text { benchmarking }\end{array}$ & $20,300,000 \mathrm{~m}^{2}$ (in 2014) \\
\hline \multicolumn{8}{|l|}{ Tokyo Metropolitan } \\
\hline Tokyo Cap-and-Trade & Cap-and-trade & $\begin{array}{l}\text { - Commercial } \\
\text { - Industrial }\end{array}$ & $\begin{array}{l}-25 \% \text { by } 2020 \\
\text { and }-30 \% \text { by } \\
2030 \text { from } 2000 \\
\text { levels }\end{array}$ & $72 \%$ (in 2013) & 2010 & $\begin{array}{l}1,300 \text { facilities }^{d} \text { (in } \\
2015 \text { ) }\end{array}$ & $\begin{array}{l}\text { - } 0.2 \% \text { of total number of } \\
\text { commercial/industrial } \\
\text { facilities } \\
\text { - } 20 \% \text { of metropolitan } \mathrm{CO}_{2} \\
\text { emissions }\end{array}$ \\
\hline \multicolumn{8}{|c|}{$\begin{array}{l}\text { Notes } \\
\text { a For Hong Kong and Singapore this encompasses the entire country } \\
{ }^{\mathrm{b}} \text { First year of programme implementation and not the year the ordinance or law was adopted } \\
\mathrm{c} \text { Total number of buildings subject to benchmarking scheme } \\
{ }^{\mathrm{d}} \text { A facility can encompass several buildings }\end{array}$} \\
\hline
\end{tabular}




\section{Innovation through diffusion}

\subsection{Key policy models}

Scholars point out stark differences between mandatory (compliance mandated by law and regulations) and voluntary approaches to governing urban climate and resiliency challenges (Huag et al., 2010; Van Der Heijden, 2014). This distinction informs our categorisation of six policy models in Table 2 (also indicated for each city in Table 1). Although examined in isolation below, we observed that cities readily combine several mandatory models into single programmes.

\section{Table 2 Identified policy models}

\begin{tabular}{|c|c|}
\hline Type & Description \\
\hline \multicolumn{2}{|l|}{ Mandatory } \\
\hline Benchmarking & $\begin{array}{l}\text { Mandates submission of energy/water consumption and GHG emissions data } \\
\text { for individual buildings. Allows annual monitoring of individual building } \\
\text { performance as well as comparisons with similar building types. May involve } \\
\text { public disclosure of individual building data. }\end{array}$ \\
\hline $\begin{array}{l}\text { Periodical energy } \\
\text { efficiency auditing or } \\
\text { retro-commissioning }\end{array}$ & $\begin{array}{l}\text { Mandates conducting of energy efficiency auditing or retro-commissioning at } \\
\text { specified time intervals, usually several years apart. }\end{array}$ \\
\hline $\begin{array}{l}\text { Energy efficiency } \\
\text { standards }\end{array}$ & $\begin{array}{l}\text { Mandates satisfying of minimum energy efficiency standards when replacing } \\
\text { or renovating specified building components. }\end{array}$ \\
\hline Cap-and-trade & $\begin{array}{l}\text { Mandates achievement of minimum GHG emission reduction targets for } \\
\text { individual buildings or facilities (comprised of several buildings) via internal } \\
\text { actions or trading of emissions credits. }\end{array}$ \\
\hline \multicolumn{2}{|l|}{ Voluntary } \\
\hline Capacity building & $\begin{array}{l}\text { Fosters voluntary reduction of energy/water consumption in individual } \\
\text { buildings by offering incentives such as access to knowledge on best } \\
\text { practices, technical support, finance and public recognition of programme } \\
\text { participation. }\end{array}$ \\
\hline Friendly competition & $\begin{array}{l}\text { Aims to foster significant reductions of energy/water consumption and } \\
\text { introduction of green office practices over a short time period (e.g. 12- } \\
\text { months) in a cohort of buildings and tenants competing to outperform each } \\
\text { other. Incentives include prospects of 'winning' and gaining mayoral and } \\
\text { media recognition, in addition to those in capacity building above. }\end{array}$ \\
\hline
\end{tabular}

Mandatory models dominated. They accounted for seven of the ten programmes, being mostly salient in Asia and the USA. Interestingly, this contrasts with tendencies in the wider C40 network, where non-regulatory approaches dominate climate governance 
(Schultz et al., 2015). The prevalence of mandatory models in our sample could be partly explained by growing realisations around the limited effectiveness of nonregulatory approaches in engaging large market segments around climate and energy issues (Huag et al., 2010; Van Der Heijden 2015), particularly in the building sector. We found three cities (Houston, Melbourne and Sydney) experimenting with voluntary approaches. In particular, voluntary models (and specifically capacity building) appear the preferred strategy in Australia. With prototypes of all six models previously existing in other cities, in line with our initial assumptions, we found no evidence of new policy inventions. Instead, as elaborated in Section 3.2, policy innovation occurs through diffusion (i.e. adoption and adaption).

\subsubsection{Benchmarking}

Mandatory building energy benchmarking schemes (henceforth 'benchmarking') dominated approaches in the USA (New York, Philadelphia, San Francisco and Seattle). One was observed in Singapore; the only in Asia-Pacific. Prevalence in the USA appears driven by expectations that "what gets measured gets improved" and recent advances in data management capability (Hsu, 2014). Essentially, benchmarking mandates annual submission of energy and water consumption and GHG emissions, and gross floor area (GFA). In the USA, building owners or utilities transfer energy and water consumption data to cities through the Environmental Protection Agency ENERGY STAR Portfolio Manager online platform. Energy consumption amounts are normalised firstly by GFA to attain energy-use intensity (EUI) and then secondly by accounting for annual climate variations. Benchmarking results allow building owners and managers to determine individual building energy consumption baselines, compare performance to national same type buildings (i.e. hospitals, hotels, offices etc.) and 
monitor annual changes. When benchmarking results for individual buildings are disclosed either publically (New York and Philadelphia) or to parties in a real estate transaction (San Francisco and Seattle), policymaker expectations are that owners will seek to improve performance and that market demand will tilt towards energy efficient buildings (Palmer and Walls, 2015).

\subsubsection{Periodical energy auditing or retrocommissioning}

This approach was observed twice in Asia and the USA and is commonly combined with other models like benchmarking in New York, San Francisco and Singapore. Auditing delivers an appraisal of energy performance in various building components and includes a list of capital-intensive retrofitting measures with cost and projected payback periods (Annunziata et a., 2014). Conversely, retrocommissioning concerns non-capital improvements and fine-tuning building systems to ensure optimal performance. Intervals between mandatory audits vary between cities: in Hong Kong every ten years; in Singapore every three years for cooling systems, and in New York every ten years for energy audits and retro-commissioning. San Francisco requires either an energy audit or retro-commissioning every five. Importantly, neither auditing or retrocomissioning actually mandates an improvement in energy efficiency. Like benchmarking, the logic is simply to supply information on energy performance and improvement opportunities to building owners and managers. That said, retrocommissioning, in principle, assures some level of performance improvement due to the tune-up nature of this work.

\subsubsection{Energy efficiency standards}

Energy efficiency standards for retrofitting have a unique ability to mandate a minimum 
level of operational performance (Van Der Heijden, 2014) for a specific retrofitting action. This model is thus a crucial instrument by which New York, Hong Kong and Singapore inject a greater degree of certainty and control in efforts to advance energy efficiency. Energy efficiency standards are commonly combined with other policy models such as benchmarking or auditing and retrocommissioning. Hong Kong combines ten-year auditing requirements with energy efficiency standards regulating the replacement of any four key building service installations (air-conditioning, electrical, lift/escalators and lighting). Singapore and New York are unique in that they combine this model with benchmarking. Singapore standards target only the installation or replacement of any water/air-cooled chiller, requiring adherence to a minimum Green Mark standard. Continued high performance is assured by mandating energy audits every three years. In New York, requirements are significantly more comprehensive. In addition to installing sub-metres in tenanted spaces, Local Law 88 requires building owners to upgrade all lighting fixtures once before 2025 in accordance with a local energy code stretched stricter than the state counterpart. In addition, Local Law 85 sets specific energy efficiency standards for building envelopes and mechanical, lighting and power system performance during retrofitting and also new construction.

\subsubsection{Cap-and-Trade}

As the environmental outcomes of all mandatory measures examined depend largely on building usage, Tokyo's cap-and-trade programme is highly unique since it's cap assures a predictable minimum quantity of GHG emission reductions across a building stock. Tokyo's program mandates $\mathrm{CO}_{2}$ e emission reductions in approximately 1,000 commercial (mostly offices) and 250 industrial (factories and water/sewage treatment 
plants etc.) facilities ${ }^{3}$ consuming annually in excess of $1500 \mathrm{~kL}$ crude oil equivalent. Affected facilities represent approximately $40 \%$ of citywide CO2 emissions in each sector. Until recent adoption in China (Zhang et al., 2014), for several years this was globally the only cap-and-trade targeting a single city (Rudolph and Kawakatsu, 2013). Mandated $\mathrm{CO}_{2} \mathrm{e}$ emissions reduction quantities are termed 'compliance factors'. In the first commitment period FY2010-FY2014 these are 6\% for industrial and 8\% for commercial, then $15 \%$ and $17 \%$ respectively for the second period FY2015-FY2019. Baselines are flexible, measured over any three-year average over FY2002-FY2007. As with all cap-and-trades, targeted facilities may meet reduction targets through internal measures or by procuring credits.

\subsubsection{Capacity building}

This voluntary model was confined to Sydney and Melbourne. Capacity building programmes seek to foster retrofitting and energy efficiency improvements through principally two incentive types: 'educative' and 'enabling' (Dowling et al., 2014). The former involves provision of knowledge, best practices and advice on retrofitting and reducing energy and water consumption through consultations and training with partnering organisations or city officials, member networking events and electronic bulletins etc. (Annunziata et al., 2014). Enabling incentives seek to enhance capacity to measure energy and water consumption and implement improvement measures through subsidised audits, rebates and financing support.

\footnotetext{
${ }^{3} \mathrm{~A}$ 'facility' may represent a single building, multiple buildings on the same premises, or an industrial facility.
} 
In pursuit of citywide climate neutrality by 2020, Melbourne's 1200 Buildings Program has pursued since 2010 the lofty objective of raising energy efficiency in 1200 buildings containing office space (around two-thirds of citywide commercial buildings) by $38 \%$ by 2020. To support this goal, a signatory programme was established where buildings (currently 57) sign a commitment letter to the City Mayor, pledging to reduce energy use by at least $38 \%$, measure and report energy and water consumption, and build and implement a retrofit plan. In addition to above-described enabling and educational incentives, further measures to coax industry to join the signatory 'club' include use of an official programme logo and participation plaque to improve public image and demonstrate leadership to shareholders, and events to recognise outstanding performance. Sydney's completed Smart Green Apartments programme is comparatively modest in scale and ambition. Participation was limited to 30 residential apartment buildings receiving both educative and enabling forms of capacity building to spur energy and water saving through retrofitting.

\subsubsection{Friendly competition}

This model was limited to Houston's Green Office Challenge. Participants compete over a 12-month period to rapidly decrease energy and water consumption and raise office sustainability in a 'friendly', non-regulatory ambience. Above-described educative and enabling type incentives are used to encourage buildings to participate, improve performance and disclose energy and water consumption data to fellow competitors. Further incentives come from prospects of 'winning' and receiving recognition through mayoral award ceremonies and media coverage. Houston's programme demonstrates

uniqueness on two levels. First, by moving beyond energy and water consumption data to holistically measure green office practices via indicators for waste and recycling, 
purchasing and transport modes; and secondly, by fixing a participation category uniquely for tenants, in addition to a building owner/manager category.

\subsection{Innovation through adaptation to local circumstances}

We unearthed diverse evidence that policy innovation occurs through diffusion and in the 'finer details' of policies as generic models are combined into single programmes or modified to suit local contexts. We also observed that unique local institutional, stakeholder and built environment circumstances influence the design, level of innovation and fate of programmes in various ways.

Tokyo officials heavily modified the generic cap-and-trade approach to local conditions and stakeholder demands, sparking much innovation in the process. The world-first decision to target downstream buildings was driven by a lack of industrial facilities combusting on-site and, conversely, the abundance of energy-intensive office and commercial buildings and industrial facilities. Stakeholder demands also spurred further tailoring. With building lobbies opposing a short-term trading-based framework due to the uncertainty and potential fluctuation of carbon pricing, officials opted for five-year commitment periods to spur long-term decision making and investments in retrofitting (Nishida and Hua, 2016). Opposition from already highly energy efficient buildings with significant past investments (Nishida and Hua, 2011) drove further innovation. In addition to flexible three-year baseline periods, a specially designed building certification scheme allows facilities to reduce compliance factors by $50 \%$ for 'top-level' certification and $25 \%$ for 'near top-level' if meeting energy efficiency and sustainability criteria set by TMG (2015). With industry also expressing concern over difficulties engaging tenants in energy reduction, two cap-and-trade legal stipulations were added. 
Tenants occupying larger than $5,000 \mathrm{~m}^{2}$ or consuming more than $6 \mathrm{GWh}$ annually in electricity must 1) submit an individual report of annual emissions and energy saving measures to TMG via the owner and 2) comply with owner or management strategies to reduce energy consumption.

Benchmarking programmes were also significantly tailored to institutional and stakeholder contexts, which both facilitated or hampered innovation. A key example concerns data disclosure. New York and Philadelphia undertook the pioneering measure of disclosing building-level results on city websites. Both cities innovated by creating interactive online maps displaying EUI, GHG emissions and Energy Star Scores for years 2013 and 2014 (City of Philadelphia, 2016a; City of New York, 2016). Compared to disclosure of raw data results as spreadsheets, these tools facilitate easy performance comparison across building types and location. Public disclosure in these cities was enabled by the competitive nature of the local building industry, who saw public disclosure as a potential driver for boosting the market competitiveness of assets. In contrast, industry resistance prevented public disclosure in Seattle and San Francisco. In other cities, local circumstances restricted initial benchmarking objectives and trailblazing in other ways. For example, institutional restrictions necessitated an abandonment of plans to target the residential sector in San Francisco, as officials lack state authority to directly regulate residential energy usage data. Interestingly, such restrictive conditions were not present in other cities such as Seattle and New York, which both target commercial and multi-family buildings. For minimum GFA thresholds, adjustment and raising was necessitated in Seattle and San Francisco. Both cities had initial ambitions of targeting buildings half the size of present GFA thresholds (see Table 2)-i.e. half of $1,858 \mathrm{~m}^{2}\left(20,000 \mathrm{ft}^{2}\right)$ and $929 \mathrm{~m}^{2}\left(10,000 \mathrm{ft}^{2}\right)$ respectively. Yet these 
were abandoned once it was realised that this would require resource-constrained officials to manage an additional 9,000 and 11,000 smaller buildings respectively.

Local contexts affected voluntary programmes too, triggering pioneering approaches. In Houston, they even influenced the choice of policy models. Building industry consultations revealed a preference for bottom-up solutions over top-down policy mandates, triggering the adoption of a voluntary 'friendly competition' model. Melbourne's programme appropriated the Property Assessed Clean Energy (PACE) model from the USA to tackle financing challenges-assumed as the major roadblock to retrofitting for citywide building owners. The resulting Environmental Upgrade Agreement finances retrofitting by tapping private lending institution funds. Loan repayments are collected through city taxes and transferred to the lender. This tripartite agreement can be fixed to a building and passed to the new owner in the event of a sale. Local institutional circumstances however prohibited direct replication of the generic PACE model. Absence of Australian municipal bond markets and low liquidity and debt levels in local governments led to allowing participating property owners to negotiate financing directly with preferred financial institutions weilding attractive interest rates. It was also hoped this would mitigate building industry wariness of direct financial arrangements with government. 


\section{Evaluation: Impacts, challenges and}

\section{countermeasures}

Here we draw on emerging evidence in the surveyed programmes to examine observed and potential impacts (categorised as environmental, market and social), challenges and countermeasures for the six policy models identified. Findings are summarised into Table 3 (mandatory models) and Table 4 (voluntary models), with key messages highlighted and elaborated below.

\subsection{Benchmarking}

Of the five mandatory benchmarking programmes, limited evidence of mid-term effectiveness (3-5 years) has emerged from San Francisco and New York. San Francisco results show that for 176 properties submitting benchmarking information annually for five years (2010-2014), weather-normalised median site EUI has dropped 7.9\% and GHG emissions 16.9\% (City of San Francisco, 2015). Yet this cohort represents only $9.5 \%$ of all buildings benchmarking in $2015^{4}$. In New York, four years of results covering 2010-2013 and buildings submitting for two or more years and passing data cleaning tests (US DOE, 2015) show that weather-normalised source EUI dropped $5.7 \%$. This is despite a $4.2 \%$ citywide increase in GDP and $8 \%$ reduction in electricity prices over this period. Energy consumption reductions were most significant in offices and colleges/universities. Across all buildings, a 9.9\% decrease in GHG emissions was detected. Yet several reasons prevent attribution of results to benchmarking. These include reduced operational capacity of many office buildings from damage following

\footnotetext{
${ }^{4}$ In 2015, 1,847 buildings were required to submit benchmarking data in San Francisco. However, only $9.5 \%$ of these have submitted for three consecutive years due to the successive dropping of minimum GFA thresholds for affected buildings. This dropped from $4645 \mathrm{~m}^{2}(50,000$ $\left.\mathrm{ft}^{2}\right)$ in 2011 , to $2,323 \mathrm{~m}^{2}\left(25,000 \mathrm{ft}^{2}\right)$ in 2012 , and to $929 \mathrm{~m}^{2}\left(10,000 \mathrm{ft}^{2}\right)$ in 2013.
} 
Hurricane Sandy in 2012 and possible impacts from another programme 'NYC Clean Heat' to phase out heavy oil use, especially in multifamily residential (City of New York, 2014). Experiences from other cities suggest that short-term impacts (1-3 years) are slow to emerge, and attribution difficult. In Philadelphia, Seattle and Singapore, results show mostly negligible changes in EUI. In Philadelphia, results for all submitting buildings show a $0.3 \%$ decrease in weather-normalised site EUI over 2012-2014 (City of Philadelphia, 2016b); in Seattle a 0.6\% decrease over 2012-2013 (City of Seattle, 2015) and in Singapore a 4.6\% decrease over 2013-2014 (BCA, 2015). Benchmarking is therefore not a short-term fix to advancing building energy efficiency and reducing citywide GHG emissions. Even when reductions of energy consumption or GHG emissions are detected, attribution to individual programmes is difficult, and requires several years of results.

Evidence from New York suggests that benchmarking may trigger job creation and economic impacts. Modelling shows that benchmarking for all affected New York buildings over 2011-2014 has sparked 39 directly-related benchmarking jobs, and over 3,000 more to achieve the above energy savings (US DOE, 2015). Yet evidence suggests that four years of reporting has not sufficed to bring large numbers of building owners to retrofit. Attribution issues aside, above reported energy savings in New York are estimated to exceed US\$267,000,000. As further market outcomes, some cities link benchmarking to a rise in green building and energy efficiency certifications (e.g. LEED, Energy Star and Green Mark etc.). Evidence, however, of increased rental premiums for highly performing benchmarked buildings is low (US DOE, 2015). 
Social impacts from benchmarking are significant. They include increased transparency around energy efficiency of individual assets for real estate actors (and the public if disclosed) and improved awareness and engagement to climate, energy and sustainability issues in the building community (US DOE, 2015). Such educational impacts usually follow a transition in outreach strategies, as officials shift from enforcement and technical assistance in early years to demonstrating how benchmarking data can facilitate improved energy management and reduced running expenses in later years (City of Seattle, 2014). Equally significant is learning that benchmarking datasets can facilitate for scholars, policymakers and the building industry. This can concern areas such as energy intensive building profiles, actual performance of LEED and Energy Star (e.g. Hsu, 2014), and impacts of other targeted building policies.

We found self-reported data accuracy from benchmarking a constant preoccupation for officials, and a major factor behind attribution difficulties. As common culprits, cities underscored incorrect manual entries for energy/water consumption, GHG emissions and GFA, difficulties in identifying these, and technical flaws in reporting methodologies from benchmarking service providers. In the absence of penalties for incorrect data entries, benchmarking programmes require development of error identification and data cleaning tools. Another important strategy is utility co-operation to enable automated data uploading and transfer to cities (achieved in Seattle, San Francisco and Singapore). This eliminates manual entry of energy (electricity, gas and steam) and water consumption amounts. Other observed challenges include difficulties for owners in obtaining data from tenants for building-level aggregated data purposes, which can affect ability to comply with submission deadlines. Commonly cited reasons include 
direct contracts between tenants and energy suppliers or tenant unwillingness to provide necessary data, especially in cases of high energy consumption. A further challenge for officials concerns eventual needs to move beyond enforcement of data submission towards measures to improve market appreciation and public value of energy efficiency performance data. Although public disclosure of individual building data can facilitate this, benchmarking ultimately requires incentives and polices to raise the energy performance of laggard buildings and foster retrofitting. A final limitation concerns the value of annual EUI for understanding building energy consumption. Officials emphasised the eventual need for monthly or seasonal data from Portfolio Manager to better ascertain energy intense periods.

\subsection{Periodical energy efficiency auditing or retrocommissioning}

The tune-up nature of retrocommissioning (and chiller auditing in Singapore) guarantees some degree of energy efficiency improvement. However, since auditing does not generally involve tune-up work, environmental impacts are highly unpredictable. Building owners are under no obligation to act on identified energy improvement measures. However, if implemented, various market impacts could manifest. First, energy expenditures could be significantly reduced. The City of San Francisco (2013), for example, reported that the first round of energy audit and retrocommissioning results submitted in 2013 identified US $\$ 6,000,000$ in annual energy savings opportunities. Second, retrofitting and low-carbon building technology markets can be stimulated. Energy saving opportunities identified in San Francisco represent approximately US\$10,700,000 in investments. Third, periodical auditing and retrocommissioning requirements can trigger new workforce formation. This was observed in Hong Kong and Singapore. Social impacts are highly important and 
particularly related to the educative nature of audits. Since results outline potential retrofitting actions, costs, payback periods and weak spots in building energy systems and management, building owners and managers receive valuable financial arguments to take action. Furthermore, submission of auditing results to cities (as in San Francisco, New York and Hong Kong) can provide officials with an inventory of installed building equipment (HVACs and lighting etc.) and structural characteristics (envelope types etc.) across a building stock, together with common upgrade opportunities. This qualitative data can complement benchmarking programmes - which provide operational dataand inform future policy and support measures. In the case where public display of auditing results is mandated, as in Hong Kong, auditing requirements can also provide feedback on building energy performance to the public.

As potential challenges, the most significant concern limitations in bringing building owners to act upon results. Reliance on government subsidies and finance schemes to incite action demands large financial resources and passes retrofitting costs to tax payers (Nishida and Hua, 2011). A second challenge involves needs to assure that auditors and engineers adhere to a common code of practice and engineering guidelines. Sloppy or inconsistent auditing or retrocomissioning can heavily reduce environmental impacts of equipment tune-ups or identification of improvement opportunities. Demonstrated countermeasures in Hong Kong include mandatory government training and registration for 'Registered Energy Assessors', and in San Francisco, the use of industry guidelines (from American Society of Heating, Refrigeration and Air-Conditioning Engineers) for controlling energy auditing scope and depth. 


\subsection{Energy efficiency standards}

The major, anticipatable environmental impact from this model is assurance that replaced or newly added building systems confirm to specific energy efficiency criteria. As in lighting requirements for the Local Law 88 of New York's Greater, Green Buildings Plan, energy standards can be constantly updated to reflect advances in technology and costs. Potential market impacts of this model are important. First, specific requirements for key building systems such as HVAC, elevators, escalators, lighting and electrical systems (e.g. Hong Kong and Singapore) and building shells (e.g. Local Law 85 in New York) stimulate demand for conforming low-carbon technologies. Second, officials expressed expectations that demand would increase for new and existing buildings conforming to new levels of energy efficiency as newly installed energy efficient technologies penetrate the market, creating new norms. Additionally, this would contribute to fostering low-carbon building design and construction jobs specialising in energy efficient construction. Adoption of energy efficient building systems and shell components would also assure decreased energy expenditures for owners over the lifetime of the investment. A potential social benefit could include easier decision making for building owners when weighing up various retrofitting technologies, since standards would create baseline, socially-acceptable technologies.

A key limitation of energy efficiency standards for retrofitting is that they take effect only at the time of a retrofit. Retrofitting timing is influenced by equipment and building lifetimes (City of Melbourne, 2015) and long-term upgrade investment strategies, which unfold over decades. Raising operational performance of core building installations across an entire building stock through energy efficiency standards can thus require decades. Secondly, since they define minimally socially acceptable norms, there is little 
incentive for building owners to invest in higher energy performance (Nishida and Hua, 2011). A third challenge concerns tracking of code conformance during a retrofit, as enforcement falls on the shoulders of private sector certifiers and engineers. As with auditing and retrocomissioning, inconsistent certification can nullify environmental and economic benefits. Strategies are thus required to ensure that certifiers abide to uniform guidelines. As an exemplary countermeasure, Hong Kong has limited certification and auditing of targeted building equipment to government trained and registered energy assessors.

\subsection{Cap-and-trade}

Tokyo has data demonstrating potential effectiveness of cap-and-trade approaches. With the first compliance period FY2010-FY2014 now ended, a 25\% reduction has been achieved from baseline $\mathrm{CO}_{2}$ emissions of $13,627,000 \mathrm{t}-\mathrm{CO}_{2}$ (TMG, 2016). Reductions were significant each year; a 13\% reduction was achieved in the first, $22 \%$ in the second and third, and $23 \%$ in the fourth. Cumulative reductions for FY2010FY2014 measure $14,281,000 \mathrm{t}-\mathrm{CO}_{2} \mathrm{e}$. High predictability and control over GHG emission reductions is innate to the cap-and-trade model (Serre et al., 2015). However, these rapidly achieved results were unanticipated. They far exceed emissions cap reductions for the first (8\%) and second compliance period (17\%), which finishes in 2020. Interestingly, these results depend on using a fixed carbon intensity factor of 0.382 kg$\mathrm{CO}_{2} / \mathrm{KWh}$ for electricity for the first compliance period. Yet if factoring in the increased carbon intensity of electricity (set to $0.489 \mathrm{~kg}-\mathrm{CO}_{2} / \mathrm{KWh}$ for the second compliance period) following the 2011 Fukushima disaster and the subsequent closure of nationwide nuclear reactors, actual $\mathrm{CO}_{2}$ reductions for the first four years diminish to approximately 3\% (TMG, 2015). Consequently, this $28 \%$ increase of electricity carbon 
intensity has almost eliminated the $\mathrm{CO}_{2}$ benefits of a drastic reduction in energy intensity $\left(\mathrm{MJ} / \mathrm{m}^{2}\right)$ for affected facilities in FY2013 from baselines, with offices improving $27 \%$ (Nishida and Hua, 2016).

Being a market instrument, cap-and-trade economic impacts can be significant. A carbon market has emerged in Tokyo. Yet several characteristics distinguish this from counterparts in the EU and North America. First, the Tokyo market is closed not stock exchange traded, tightly regulated, and limited to domestic credits ${ }^{5}$. Second, sale of emissions allowances is restricted to those remaining after annual reduction obligations are met. Consequently, trading volumes are small whilst carbon prices are the highest in the world. During early years, carbon prices averaged around JPY 9,600 and later dropped to around JPY 3,500 during FY2015 (Nishida and Hua, 2016). With high prices reflecting low supply, as of 30 September 2015, trades over FY2010-FY2010 totalled 69 transactions and a mere $107,169 \mathrm{t}-\mathrm{CO}_{2} \mathrm{e}$ relative to baseline emissions of $13,627,000 \mathrm{t}-$ $\mathrm{CO}_{2}$

The bulk of GHG emission and energy savings were therefore achieved through retrofitting and onsite measures. Annual reports submitted by affected facilities (Nishida and Hua, 2016) generate valuable qualitative and quantitative data on energy saving measures. These include capital-intensive upgrades such as high efficiency heat source equipment (contributing a 133,000 t- $\mathrm{CO}_{2}$ e reduction over the first commitment period), high-efficiency pumps for air-conditioning $\left(28,000 \mathrm{t}-\mathrm{CO}_{2} \mathrm{e}\right)$, high-efficiency air

\footnotetext{
5 Most domestic trading involves renewable energy credits or direct transfers of excess emission credits between entities.
} 
conditioning such as turbo chillers $\left(27,900 \mathrm{t}-\mathrm{CO}_{2} \mathrm{e}\right)$, high-efficiency lighting equipment and controls $\left(71,700 \mathrm{t}-\mathrm{CO}_{2} \mathrm{e}\right)$ and LED lighting $\left(49,400 \mathrm{t}-\mathrm{CO}_{2} \mathrm{e}\right)$.

The success demonstrated by cap-and-trade in Tokyo in rapidly and drastically reducing final energy consumption and $\mathrm{CO}_{2}$ emissions is highly contextual. As mentioned, it was largely achieved by proactive investments in retrofitting by affected facilities. This resulted from both policy design and industry mentality. On the former, the programme is characterised by five-year compliance periods, which encourage long-term and strategic industry investing in retrofitting. Also, carbon trading was designed only as a back-up option for facilities unable to meet emission reduction obligations internally. As mentioned, emissions allowance trading is restricted to excess permits after annual reductions obligations are met. This results in a low circulation volume and high prices. On the latter, industry mentality led to the non-reliance on short-term trading. As expressed during consultations with city officials (Nishida and Hua, 2011), industry stakeholders desired to meet emission reduction obligations primarily through internal measures and strategic long-term investment in equipment upgrade.

As additional market impacts, job creation also occurred. ESCOs numbers have expanded from increased demand for energy consulting, and similarly, verification agencies owing to requirements that all submitted data be checked by TMG registered agencies. Market impacts have also come from the incentive scheme for reducing compliance factors for 'top-level facilities' (see Section 3.2). From April 2010 to March 2014, 40 facilities were certified as 'top-level' and 47 as 'near-top level' (TMG, 2015). By functioning as a new building certification boosting market competitiveness for 
qualifying facilities, certifications have spurred retrofitting and innovative new building design as facilities seek to reduce future emissions reduction obligations.

Experiences in Tokyo suggest important social impacts. First, TMG administered surveys (Nishida and Hua, 2016) show $72 \%$ of affected top-level management teams becoming more attentive to energy saving measures. This shift was largely influenced by legal requirements that facilities appoint an on-site building technician to report on energy efficiency and GHG emission matters to senior management. This has helped overcome communication gaps between technicians on the ground, with expertise in potential energy reductions, and top boardroom decision-makers. Second, tenant and owner relations around energy efficiency has improved in $63 \%$ of facilities. This occurred through the aforementioned legal stipulation that high energy consuming tenants cooperate with building owner initiated reduction measures and report GHG emissions to TMG. Finally, another demonstrated social impact is the ability to bring about changes in building usage and management. Survey results (Nishida et al. 2016) also reveal important 'soft' measures. These include relaxing illumination standards, summer air-conditioning temperatures, air-conditioning operation hours, summer dress codes and cooling with outside air. Although dwarfed by retrofitting impacts, by FY2015 these soft measures contributed approximately $61,941 \mathrm{t}-\mathrm{CO}_{2} \mathrm{e}$ of reductions.

In terms of key challenges encountered, higher than expected emissions reductions achieved during the first compliance period have led to an oversupply of excess emissions credits for the second period. It is expected this will drive a drop in carbon prices, challenging the financial incentive to continue meeting emissions reduction obligations with onsite measures such as retrofitting. The announcement of significantly 
higher emissions reduction targets for post-2020 is therefore needed to sustain momentum and early success. Other important factors and incentives helping overcome industry resistance to a cap-and-trade in Tokyo deserve mentioning. The former ' $\mathrm{CO}_{2}$ Emission Reduction Program' from 2002-2005 played a crucial role.

Superseded by the cap-and-trade, this was a mandatory GHG emissions reporting and public disclosure initiative for large emitters. Similar to benchmarking schemes, this did not mandate actual reductions. Although the initiative's impact on reducing GHG emissions was not as high as officials hoped, it fostered valuable relations and trust with industry. In addition, it secured detailed self-reported data on emissions trends, installed building systems, and energy consumption reduction potential. During the transition to the cap-and-trade, this helped counter industry arguments that further $\mathrm{CO}_{2}$ reductions were impossible, and also, selection of an ambitious and equitable cap (Nishida and Hua, 2011). Additionally, the aforementioned top- or near-top level certification scheme, which rewards past efforts for highly performing facilitates, also proved an invaluable countermeasure to industry resistance.

\subsection{Capacity building}

City official expectations suggest that potential environmental impacts of voluntary capacity building programmes include the fostering of long-term building management strategies, leading to reductions in energy and water consumption and GHG emissions. Actual evidence of such outcomes however lacks in the sample. Without mandatory energy and water consumption reporting in citywide office buildings, Melbourne officials are unable to gauge programme effects on the larger building population. In the signatory component, officials are also unable to determine progress towards the $-38 \%$ energy consumption target for 57 participating buildings. Voluntary agreements have 
proved incapable of bringing building owners to periodically report energy and water consumption and monitor outcomes of retrofitting. Sydney officials did not monitor the energy and water consumption outcomes of their programme.

Capacity building approaches demonstrated some potential to foster retrofitting. Sydney reported a $37 \%$ uptake of sustainability improvements and retrofitting recommendations outlined in subsidised audits for the 30 participating apartment buildings (City of Sydney, 2013). Participation of multifamily buildings with motivations to retrofit was certainly an influencing factor. There is limited evidence of retrofitting impacts from Melbourne's programme. A third-party evaluation revealed that 10 of 57 signatory component participants completed a retrofit and 14 are currently underway. Yet many of these were already planning retrofits before joining. As for the wider office building population, a survey of 387 buildings (City of Melbourne, 2015) shows that retrofitting activity has increased from $25 \%$ of respondents during $2008-2013$ to $37 \%$ during 2010-2015. Yet again, attribution to the 1200 Buildings programme is troublesome, predominantly for the reason that most sampled buildings have not engaged with the programme's capacity building measures.

Regarding social impacts, evidence in Sydney and Melbourne suggests the building community's collective capacity to improve environmental performance can be enhanced through programme educative and functions. This occurs from exposure to best practices and energy efficiency improvement opportunities from peer buildings, face-to-face meetings with city or industry technical experts, electronic newsletters, and also, guidance in formulating long-term asset maintenance and replacement master plans. Sydney and Melbourne also demonstrated a special ability to involve 
smaller buildings, which typically slip through the nets of mandatory schemes setting explicit thresholds for minimum GFAs. Another demonstrated impact concerns enabling measures improving access to finance for retrofitting. This occurred by promoting uptake of city and state financial assistance and subsidies, typically through information provided in auditing results. In Melbourne, this occured notably through the aforementioned Environmental Upgrade Agreement, so far lending over AU\$12.6 million to finance retrofitting and rooftop solar projects.

As potential challenges, widespread building industry engagement can prove troublesome in the absence of mandatory frameworks (Van Der Heijden, 2014). For instance, the 57 buildings joining the signatory component of Melbourne's programme represent a fraction of the targeted population of 2256 office-space containing buildings. Seemingly for local cultural reasons, efforts to recruit new buildings to the signatory programme through public recognition of outstanding performance have failed. With recruitment now abandoned, officials found that many buildings value privacy and prefer to retrofit without public recognition. Significant difficulties are also arising when engaging smaller and older buildings. Relative to larger corporate sector counterparts, smaller buildings are typically owned by individuals, perceive less benefit in retrofitting, and lack asset master plans and long-term strategies for upgrading equipment. Reliance on financial capacity raising, should also anticipate challenges. Despite attractiveness as a low-risk finance option for owners, the Environmental Upgrade Agreement has to date seen only seven partakers across the city, disappointing lofty political expectations. Contrary to expectations that access to finance was the major barrier to retrofitting, officials learned that most buildings prefer to self-fund upgrades (City of Melbourne, 2015). Potential explanations are wariness of 
long-term involvement with government, burdensome application procedures, and high minimum loan thresholds (originally $A \cup \$ 500,000$ ).

\subsection{Friendly competition}

Although confined to Houston's Green Office Challenge, several observations can be made on this model. For environmental impacts, due to the competitive element and focus on a 12-month interval, rapid and significant reductions in energy and water consumption and GHG emissions can be expected over a short period. In the first challenge year 2011, a 6\% reduction of source EUI was achieved from 2009 baselines for 375 participants (both tenanted spaces and whole buildings) comprising 6,967,728 $\mathrm{m}^{2}$. In the second challenge year (October 2014 to October 2015), average source EUI dropped by $17 \%$ for $3,483,864 \mathrm{~m}^{2}$ of offices. However second year baselines range from 2008 to 2015, since many participants were benchmarking and measuring energy consumption before programme participation. The precise contribution of the 12-month competition period is therefore unclear.

In terms of potential market impacts, officials expressed confidence that the programme has contributed to a citywide rise in LEED existing building certifications. Although uncertainty surrounds the programme's precise contribution, demonstrating that smaller and existing buildings can obtain LEED or Energy Star status, and then diffusing these experiences amongst participants, is a key outcome. Social impacts were significant. For example, the programme demonstrated a unique ability to involve tenants and thereby foster cooperation with owners regarding energy and sustainability issues. This was facilitated by the aforementioned creation of separate tenant and owner/manager categories and scoring systems. Also important, this model nourished 
co-operative relationships around energy usage between city officials and frontrunner buildings - with significant industry influence and capacity to trigger widespread change-in a friendly, non-mandatory ambience. This allowed officials to collect empirical data on baseline emissions, reduction potential and outcomes of certain actions in key city office buildings. As shown in Tokyo, these relationships and datasets can potentially prove important for informing later transitions to mandatory frameworks.

Houston experiences suggest potential challenges for this competition model. Firstly, securing sustained participation of individual buildings and tenants over consecutive competition years has proved difficult. Second, whilst consulting with stakeholders during the design phase, officials encountered concerns that focusing on baseline energy performance would alienate both laggard buildings unable to make necessary investments in retrofitting, and frontrunners already attaining a high level of energy efficiency. To overcome this, the emergent programme encouraged participation of frontrunners by rewarding mentor 'badges' and highlighting their advanced performance as desirable benchmarks for laggards. Officials also experienced challenges spurring uptake of a specially designed funding mechanism to cover $20 \%$ of material and labour costs for energy upgrades. Attractiveness was low due to shortterm funding availability reflecting the 12-month competition period. This triggered realisations that longer funding availability is required for coaxing retrofitting in friendly competitions, especially for public institutions with long-planning horizons. 
Table 3 Observed and potential impacts and challenges (mandatory models)

\section{Environmenta}

Type

Benchmarking - Reductions in energy/water usage intensity and GHG emissions

\section{Market}

Job creation through increased deman for ESCOs and benchmarking service providers

- Savings in energy expenditures following improved building management or retrofitting

- Growth of green building and energy efficiency certifications (e.g. LEED, Energy Star, Green Mark etc.)

- $\quad$ Stimulation of retrofitting
- Learning for scholars, industry

\begin{tabular}{ll}
\hline $\begin{array}{l}\text { Periodical } \\
\text { energy }\end{array}$ & $\begin{array}{l}\text { Assuredness that building } \\
\text { systems operate at most } \\
\text { efficiency }\end{array}$ \\
$\begin{array}{l}\text { enditing or retro- } \\
\text { commissioning }\end{array}$ & $\begin{array}{l}\text { through tune-ups, } \\
\text { enhancing future energy } \\
\text { efficiency }\end{array}$
\end{tabular}

Job creation through increased de
for auditors and energy engineers

- Savings in energy expenditures from

$\begin{array}{ll}\begin{array}{l}\text { Energy } \\ \text { efficiency codes }\end{array} & \begin{array}{l}\text { Assuredness that newly } \\ \text { installed building system } \\ \text { for retrofitting }\end{array} \\ & \begin{array}{l}\text { components conform to } \\ \text { specific energy efficiency } \\ \text { norms }\end{array}\end{array}$

Energy efficiency retro-commissioning and implementation of capital intensive upgrades

- Implementation of retrofitting measures outlined in auditing

$$
\text { payback periods }
$$

- Generation of 'inventory' like data for policymakers, showing a) installed building equipment and components and b) energy efficiency opportunities across building stock

- Increased uptake of energy efficient retrofitting technologies and building system components

- $\quad$ Stimulation of demand for buildings meeting energy efficiency norms

- Savings in operational expenditures from high efficiency building system components

- Establishment of minimum energy efficiency norms for retrofitting options

\section{Social}

- Provision of baseline and annual energy consumption allows building owners/managers to implement improvement measures

- Transparency of building energy efficiency for prospective buyers/tenants and public

- Greater attention to climate, energy and sustainability issues in building sector and policymakers from analysing operational performance of building stock

Provision of information to building owners on potentia

\section{Challenges or limitations}

- Accuracy of self-reported data from owners and benchmarking service providers

- $\quad$ Attributing observed

energy/water/GHG reductions to benchmarking

- $\quad$ Eventual need to move beyond compliance towards enticing action and fostering market appreciation of energy efficiency data

- Absence of regulatory power to mandate improvements in building performance

- Inability of current annual reporting norms to supply monthly or seasonal data

- $\quad$ Bringing building owners to implement measures identified in auditing results

- $\quad$ Need to assure that auditors and retro-commissioners adhere to a common code of practice building owners choosing various

- $\quad$ Enforcement and monitoring of compliance with energy codes during retrofits

- $\quad$ Little incentive for building owners to invest in higher efficiency than required norms 
\begin{tabular}{lll} 
Cap-and-trade $\quad \begin{array}{l}\text { Predictable minimum } \\
\text { reductions in GHG }\end{array}$ \\
\hline
\end{tabular} emissions

- Reductions in energy consumption

- Purchasing of renewable energy
- Creation of carbon market

- Stimulation of retrofitting and uptake of energy efficient building system components

- Job creation through growth of service providers such as data verification agencies and ESCOs

- Savings in energy expenditures

- $\quad$ Spurring of green building innovation in retrofitting and new construction
- $\quad$ Overcoming of inattentiveness to onsite energy usage and improvement potential in toplevel management

- $\quad$ Activation of onsite building manager/engineer expertise

- Promotion of tenant and owner co-operation regarding energy usage

- $\quad$ Triggering of building usage changes
- Requirement of innovative measures to overcome industry resistance and reward past performance

- Tenant engagement in energy conservation or retrofitting investment

- $\quad$ Selection of equitable yet ambitious cap, both at initial launch and in future compliance periods

- Ensuring scarcity of credits to increase carbon price and drive onsite reduction measures

\section{Table 4 Observed and potential impacts and challenges (voluntary models)}

\begin{tabular}{|c|c|c|c|c|}
\hline Type & Environmental & Market & Social & Challenges or limitations \\
\hline $\begin{array}{l}\text { Capacity } \\
\text { building }\end{array}$ & $\begin{array}{l}\text { Fostering of long-term } \\
\text { management and } \\
\text { retrofitting strategies for } \\
\text { achieving reductions in } \\
\text { energy/water usage and } \\
\text { GHG emissions }\end{array}$ & $\begin{array}{l}\text { - } \quad \text { Stimulation of retrofitting activities } \\
\text { - Savings in energy expenditures }\end{array}$ & $\begin{array}{l}\text { Enhancement of capacity to } \\
\text { improve environmental } \\
\text { performance and retrofit from } \\
\text { educative and enabling } \\
\text { measures } \\
\text { - Securing of smaller building } \\
\text { participation } \\
\text { Establishment of city-industry } \\
\text { relations in a friendly, non- } \\
\text { mandatory ambience } \\
\text { Collection of data for informing } \\
\text { other mandatory policies }\end{array}$ & $\begin{array}{l}\text { Development of incentives to secure } \\
\text { engagement and spur improvement } \\
\text { measures in significant portion of the } \\
\text { building stock in absence of mandatory } \\
\text { frameworks } \\
\text { - } \quad \text { Engagement of smaller, older buildings } \\
\text { Bringing building owners/managers to } \\
\text { voluntarily submit energy consumption } \\
\text { data } \\
\text { Low-attractiveness of government } \\
\text { mediated financing with private } \\
\text { institutions }\end{array}$ \\
\hline $\begin{array}{l}\text { Friendly } \\
\text { competition }\end{array}$ & $\begin{array}{l}\text { Rapid reductions in } \\
\text { energy/water usage and } \\
\text { GHG emissions over } \\
\text { short period (e.g. 12- } \\
\text { months) }\end{array}$ & $\begin{array}{ll}- & \text { Savings in energy expenditures } \\
\text { - } & \text { Fostering of LEED or Energy Star } \\
& \text { certification for existing buildings }\end{array}$ & 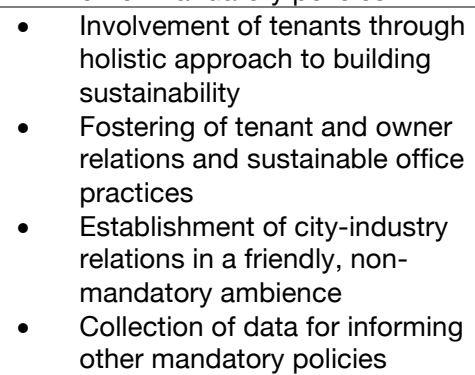 & 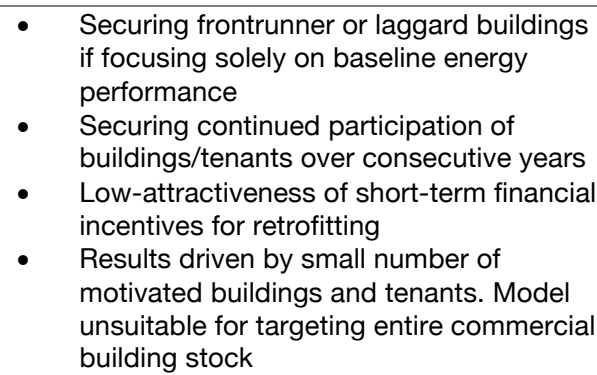 \\
\hline
\end{tabular}




\section{Conclusion}

This paper examined ten city programmes in Asia-Pacific and the USA to paint a comparative, multi-national perspective on emerging policies in the C40 PBEN network to advance energy efficiency and retrofitting in existing, private sector buildings. We identified six policy models, also characterising their unique potential impacts and challenges. Mandatory approaches included benchmarking, periodical energy audits or retro-commissioning, energy efficiency standards and cap-and-trade. Several cities are combining the first three. Two voluntary models were identified; friendly competition and capacity building. Overall, our sample demonstrated experimentation with benchmarking in the USA, comprehensive regulation in Asia, and voluntary approaches in Australia. As hints for future policy directions, overall mandatory measures are yet to explicitly target tenant energy usage, single-family residential, and small to medium buildings.

Supporting other studies (Jordan and Huitema, 2014b), we demonstrated that invention of new policies is not a precondition to innovation in policy design and implementation. Supporting Bulkeley et al. (2014a), we found that policy innovation partly arises from necessity - as unique and local institutional, stakeholder and built environment circumstances prevent cities transposing 'pre-fabricated' policies from peers. Innovation occurs through tailoring and adding new features to generic policy models, and by combining multiple models into single programmes. We also showed that local conditions may necessitate compromising initial ambitions, hampering the ability to innovate, and therefore, subsequent policy impacts. From the perspective of 
sustainability transitions literature, this evidence suggests that 'landscape' cultural factors (Geels, 2002) outside policymaker control will largely impact the design and outcomes of programmes. These include building industry attitudes to energy consumption management, retrofitting and climate change, and willingness to be governed.

From an evaluation viewpoint, we identified varied environmental, economic and social impacts. We thus emphasise the need to look beyond environmental indicators when evaluating climate, energy and resilience policies. Overall, environmental outcomes are particularly slow to emerge, plagued by attribution challenges, and require further monitoring. One exception was the friendly competition model, which demonstrated an ability to bring about rapid and attributable reductions in energy consumption over a short-term period. Suitability for driving long-term improvements over several years however seems limited. Driven by unique local circumstances and design features, the cap-and-trade model was another exception, generating rapid, sustained and outcomes. It vastly exceeded initial GHG reduction objectives and stimulated much retrofitting in Tokyo. Success factors include industry willingness to invest in retrofitting measures without reliance on short-term carbon trading, measures to ensure high carbon prices, and five-year compliance periods to foster long-term investment. Attribution of impacts was possible due to annual survey data taken from affected facilities. Recent introductions of cap-and-trade in China and Korea (Serre et al., 2015) suggest these results are noted globally, and that this model is undergoing diffusion across Asia.

Regarding benchmarking, overall evidence of short-term effectiveness in advancing 
energy efficiency and retrofitting is mixed, and plagued with attribution challenges. The most promising results appeared after four to five years in New York and San Francisco. Major implementation challenges include data accuracy issues from self-reporting and difficulties for building owners in securing aggregate property data. For officials, there is an eventual need to move beyond initial enforcement of data reporting towards measures to bring laggard buildings in line with desirable benchmarks. Increasing the public visibility and market value of results is essential. In the short-term, the principal value of benchmarking for policymakers lies in the data itself. Results allow policymakers to create a baseline and better understand the energy efficiency of a building stock, and potentially, formulate additional mandatory or voluntary measures to incite buildings to act upon annual results. Although we did not examine impacts on water consumption, we highlight this as an underappreciated area meriting future enquiry by other scholars.

Anecdotal evidence of market impacts such as increased green jobs existed in many cities, yet mostly, quantitative monitoring lacks. Conversely, much evidence was found for significant social impacts across all models. A common outcome was the ability of programmes to raise industry awareness of energy efficiency performance in buildings, and also, increase building owner capacity to measure performance and implement energy management strategies and improvements. Although voluntary approaches grapple with incentive difficulties in the absence of regulations, we draw attention to their unique and potential ability to foster policymaker and industry trust in an amiable, non-regulatory ambience. We emphasised their ability to generate datasets for informing future mandatory programmes (as demonstrated in Tokyo's cap-and-trade), and potentially, complementing mandatory models through friendly competitions and 
rewarding good performance. Scholars and policymakers therefore need not view voluntary and mandatory approaches as polarities or competing options when advancing urban climate resilience and progress to city GHG emission targets. The transition in Tokyo from a carbon emissions reporting scheme (not mandating actual reductions) to a cap-and-trade (mandating reductions over five-year periods) also indicates a potential future pathway for benchmarking schemes.

Given their global weight environmentally, economically and politically, it is imperative that $\mathrm{C} 40$ cities succeed in decreasing energy consumption and GHG. However, with some exceptions, the effectiveness of surveyed programmes to advance energy efficiency in existing, private buildings is still uncertain. Further monitoring and research is required on mid- and long-term impacts; not just environmental, but also market and social.

\section{Acknowledgements}

We extend our gratitude to C40 city officials kindly donating time for this study. Special thanks to the INOGOV Climate Change Policy and Governance: Initiation, Experimentation, Evaluation workshop (12-13 March 2015, Helsinki) organisers and reviewers for their valuable feedback on an earlier conference paper version. We also appreciate the constructive comments from reviewers in this journal. 


\section{References}

Acuto, M. 2016. Retrofitting global environmental politics? Networking and climate action in the C40. In: Hodson, M., Marvin, S. (Eds) Retrofitting Cities Priorities, Governance and Experimentation. Oxon and New York: Earthscan, 107-118.

Annunziata, E., Rizzi, F., Frey, M. 2014. Enhancing energy efficiency in public buildings: The role of local energy audit programmes. Energy Policy, 69, 364-373.

Auld, G., Mallett, A. Burlica, B., Nolan-Poupart, F., Slater, R., 2014. Evaluating the effects of policy innovations: Lessons from a systematic review of policies promoting low-carbon technology. Global Environmental Change, 29, 444-458.

Berr, A., Sherwin, E., 2012. Energy Disclosure \& the New Frontier for American Jobs. Institute for Market Transformation. http://www.imt.org/resources/detail/energydisclosure-the-new-frontier-for-american-jobs, last accessed August 4, 2015.

Biesenbender, S., Tosun, J., 2014. Domestic politics and the diffusion of international policy innovations: How does accommodation happen? Global Environmental Change, 29, 424-433.

Brown, L.R., Adams, E., Larsen, J., Roney, J.M., 2015. The Great Transition: Shifting from Fossil Fuels to Solar and Wind Energy. W. W. Norton, New York.

Building Construction Authority of Singapore (BCA), 2015. BCA Building Energy Benchmarking Report 2015.

http://www.bca.gov.sg/GreenMark/others/BCA_BEBR_Abridged_FA_2015.pdf, last accessed January 01, 2016.

Bulkeley, H. 2010. Cities and the Governing of Climate Change. The Annual Review of Environment and Resources, 35:229-53.

Bulkeley, H. 2015. Can cities realise their climate potential? Reflections on COP21 Paris and beyond. Local Environment, 20 (11), 1405-1409.

Bulkeley, H. Castán Broto, V. 2012. Government by experiment? Global cities and the governing of climate change. Transactions of the Institute of British Geographers, 38(3), 361-375.

Bulkeley, H., Castán Broto, V., Edwards, G., 2014a. An Urban Politics of Climate Change: Experimentation and the Governing of Socio-technical Transitions. Oxon: Routledge. 
Bulkeley, H., Edwards, G. Fuller, S., 2014b. Contesting climate justice in the city: Examining politics and practice in urban climate change experiments. Global Environmental Change, 25, 31-40.

Burr, A., Sherwin, E. 2012. Energy Disclosure \& the New Frontier for American Jobs. Institute for Market Transformation. http://www.imt.org/resources/detail/energydisclosure-the-new-frontier-for-american-jobs

Castán Broto, V., Bulkeley, H., 2013. A survey of urban climate change experiments in 100 cities. Global Environmental Change, 23, 92-102.

City of Melbourne. 2015. 1200 Buildings Melbourne Retrofit Survey 2015. https://www.melbourne.vic.gov.au/SiteCollectionDocuments/melbourne-retrofit-survey2015.pdf, last accessed May 1, 2016.

City of New York. 2014. New York City Local Law 84 Benchmarking Report September 2014. Office of the Mayor. http://www.nyc.gov/html/planyc/downloads/pdf/publications/2014_nyc_II84_benchmar king_report.pdf, last accessed March 1, 2015.

City of New York. 2016. New York City Energy \& Water Performance Map. Mayor's Office of Sustainability. http://benchmarking.cityofnewyork.us, Last accessed April 16, 2016.

City of Philadelphia. 2014. City of Philadelphia Energy Benchmarking Report. http://www.phillybuildingbenchmarking.com/images/uploads/documents/MOS_BnchMr kRprt_R5fin_FINAL.pdf, last accessed March 1, 2015.

City of Philadelphia. 2016a. 2015 Building Energy Benchmarking. Mayor's Office of Sustainability. http://visualization.phillybuildingbenchmarking.com, last accessed May 1, 2016.

City of Philadelphia. 2016b. 2016 Building Energy Benchmarking. Mayor's Office of Sustainability. http://www.phillybuildingbenchmarking.com/wpcontent/uploads/2016/04/2016-Benchmarking-Report.pdf, last accessed May 1, 2016.

City of San Francisco, 2013. San Francisco Climate Action Strategy. 2013 Update. Department of the Environment. http://sfenvironment.org/sites/default/files/engagement_files/sfe_cc_ClimateActionStrat egyUpdate2013.pdf, last accessed July 12, 2014. 
City of San Francisco. 2015. San Francisco Existing Commercial Buildings Performance Report.

http://sfenvironment.org/sites/default/files/fliers/files/sfe_gb_ecb_performancereport.pd f, last accessed January 1, 2016.

City of Seattle. 2014. Seattle Building Energy Benchmarking Analysis Report. Seattle Office of Sustainability and Environment.

http://www.seattle.gov/Documents/Departments/OSE/EBR-2011-2012-report.pdf, last accessed March 1, 2015.

City of Sydney, 2013. A review of initial cost savings and community improvement resulting from the Smart Green Apartments Program.

http://www.cityofsydney.nsw.gov.au/_data/assets/pdf_file/0003/146829/6388_FA3_LR

_Smart-Green-Apartments-Pilot-Study-handout_covers.pdf, last accessed March 1, 2015.

Dowling, R., McGuirk, P. and Bulkeley, H., 2014. Retrofitting cities: Local governance in Sydney, Australia, Cities, 38, 18-24.

Geels, F. 2002. Technological transitions as evolutionary reconfiguration processes: a multi-level perspective and a case-study. Research Policy, 31, 1257-1274.

Guy, S., Marvin, S., Medd, W., Moss, T. 2010. Shaping Urban Infrastructures: Intermediaries and the Governance of Socio-Technical Networks. Oxon and New York: Earthscan.

Hilden, M., Jordan, A., Rayner, T. 2014. Climate policy innovation: developing an evaluation perspective. Environmental Politics, 23(5), 884-905.

Howlett, M. 2014. Why are policy innovations rare and so often negative? Blame avoidance and problem denial in climate change policy-making. Global Environmental Change 29, 395-403.

Huag, C., Rayner, T., Jordan, A. et al. 2010. Navigating the dilemmas of climate policy in Europe: evidence from policy evaluation studies. Climatic Change, 101 (3-4), 427445.

Hsu, D. 2014. Improving energy benchmarking with self-reported data, Building Research and Information, 42 (5): 641-656.

ICLEI USA. 2012. Houston Mayor Parker Announces Green Office Challenge Winners. http://www.icleiusa.org/blog/houston-mayor-parker-announces-green-office-challengewinners last accessed 12 September, 2014. 
IPCC, 2014. Climate Change 2014: Mitigation of Climate Change. Contribution of Working Group III (Chapter 9 Buildings). London and New York: Cambridge Press.

Jordan, A. Huitema, D., 2014a. Policy innovation in a changing climate: Sources, patterns and effects. Global Environmental Change, 29, 387-394.

Jordan, A. Huitema, D. 2014b. Innovations in climate policy: conclusions and new directions. Environmental Politics, 23 (5), 906-925.

Jordan, A. Huitema, D. 2014c. Innovations in climate policy: the politics of invention, diffusion, and evaluation. Environmental Politics, 23(5), 715-734.

Matisoff, D. Edwards, J., 2014. Kindred spirits or intergovernmental competition? Environ. Politics 23(5), 795-817.

Nishida, Y., Hua, Y., 2011. Motivating stakeholders to deliver change: Tokyo's Capand-Trade Program. Building Research and Information, 39 (5), 518-533.

Yuko Nishida, Ying Hua \& Naomi Okamoto. 2016. Alternative building emission-reduction measure: outcomes from the Tokyo Cap-and-Trade Program, Building Research \& Information, DOI: 10.1080/09613218.2016.1169475

Palmer, K. L., Walls, M. 2015. Can Benchmarking and Disclosure Laws Provide Incentives for Energy Efficiency Improvements in Buildings? Resources for the Future Discussion Paper No. 15-09. http://dx.doi.org/10.2139/ssrn.2564251

Rudolph, S., Kawakatsu, T., 2013. Tokyo's Greenhouse Gas Emissions Trading Scheme: A Model for Sustainable Megacity Carbon Markets. In: Kreiser, L. Duff, D., Milne, J. E., and Ashiabor, H., (Eds.) Market Based Instruments: National Experiences in Environmental Sustainability. Cheltenham UK and Northampton MA: Edward Elgar Publishers, 77-93.

Schulz, S., Bailey, T., Ast, E., Russel, B., Morris, E., Kirk, P., Frost, L., Gibbons, R., Hurst, T., O'Brien, H., Ozmumcu, A., Acuto, M., Rapoport, E., Ram, J., Hill, L. 2015. Powering Climate Action: Cities as Global Changemakers. C40 and ARUP. http://publications.arup.com/publications/p/powering_climate_action_cities_as_global_ changemakers, last accessed April 4, 2016.

Serre, C., Santikarn, M., Stelmakh, K., Eden, A., Frerk, M., Kachi, A., Unger, C., Wilkening, K., Haug, C., (Eds.) 2015. Emissions Trading Worldwide International Carbon Action Partnership (ICAP) Status Report 2015. Berlin: ICAP. 
Takagi, T., Horie, R., Trencher, G. et al. 2014. Urban Efficiency: A Survey of Building Energy Efficiency Policies in C40 Cities. Tokyo Metropolitan Government (Bureau of Environment) and C40 Cities Climate Leadership Group (London), Tokyo.

Tokyo Metropolitan Government (TMG), 2016. Tokyo Cap-and-Trade Program achieves $25 \%$ reduction after 5 th year. Bureau of the Environment.

http://www.kankyo.metro.tokyo.jp/en/files/3c08a5ad895b5130cb1d17ff5a1c9fa4.pdf, last accessed May 1, 2016.

Tokyo Metropolitan Government (TMG), 2015. Tokyo Green Building Report. Bureau of Environment, Tokyo.

http://www.kankyo.metro.tokyo.jp/en/climate/files/Tokyo_GB_eng.pdf, last accessed April 5, 2016.

United States Department of Energy (US DOE). 2015. New York City Benchmarking and Transparency Policy Impact Evaluation Report.

http://energy.gov/eere/slsc/downloads/new-york-city-benchmarking-and-transparencypolicy-impact-evaluation-report, last accessed May 2, 2016.

Van Der Heijden, J., 2014. Governance for Urban Sustainability and Resilience:

Responding to Climate Change and the Relevance of the Built Environment.

Cheltenham UK and Northampton MA: Edward Elgar Publishers.

Van Der Heijden, J., 2015. What 'Works' in Environmental Policy-Design? Lessons from Experiments in the Australian and Dutch Building Sectors. Environmental Politics, 17 (1), 44-64.

World Bank, 2010. Cities and climate change: an urgent agenda. Washington DC: World Bank.

Zhang, D., Karplusb, V. J., Cassisaa, C., Zhang, X., 2014. Emissions trading in China: Progress and prospects. Energy Policy, 75, 9-16. 